\title{
Margaret Oliphant's Prolificacy and Anxiety of Artistic Creation: A Study of Her Autobiography
}

\author{
Margaret Oliphant'ın Üretkenliği ve Sanatsal Üretim Kaygısı: Yazarın \\ Otobiyografisi Üzerine Bir Çalışma
}

\section{Seda COŞAR ÇELİK*}

\begin{abstract}
Margaret Oliphant (1828-1897) was a Scottish Victorian, considered one of the most prolific writers of the Victorian period. She was very well known in her lifetime; yet, today she is considered a minor Victorian novelist. Specialists, who discuss Margaret Oliphant as an under-represented Victorian writer, cannot escape mentioning her overproduction as the main cause of her oblivion today. As a very important piece in Margaret Oliphant's oeuvre, her Autobiography records that her prolificacy also worried the author. Writing so fast and so much made her very anxious, perhaps because she was discontented about the literary qualities of her own work. That is why the title of this article brings together what appear to be paradoxical expressions: prolificacy and anxiety of artistic creation. In her Autobiography, she cordially confesses her unhappiness, uneasiness and tough experiences both as the sole provider for a large family and as a woman writer, who never felt genuinely accomplished even though she was a very notable literary figure of her day. This article will therefore examine Margaret Oliphant's Autobiography as a confessional narrative, which reveals an exceptionally prolific woman writer's agony in respect to her profession as a writer.
\end{abstract}

Keywords: Margaret Oliphant, Autobiography, Prolificacy, Anxiety of Artistic Creation

Öz: Viktorya döneminin İskoçyalı yazarlarından Margaret Oliphant (1828-1897) döneminin en üretken yazarları arasında sayılır. Fakat, yaşadığı dönemde iyi tanınmasına rağmen günümüzde adı dönemin klasikleşmiş yazarları arasında anılmaz. Margaret Oliphant'ı ihmal edilmiş bir yazar olarak ele alan Viktorya dönemi uzmanları, yazarın aşırı üretkenliğine de değinirler, çünkü birçoğu yazarın zaman içinde unutulmasını buna bağlamaktadır. Margaret Oliphant'ın Otobiyografi'si bu üretkenliğinin aslında kendisini de endişelendirdiğini göz önüne sermesi açısından yazarın külliyatında önemli bir yer tutar. Çok hızlı ve çok fazla üretiyor olması, eserleri edebi açıdan kendisini de tatmin etmediğinden olsa gerek, Margaret Oliphant'ı kaygılandırıyordu. Bu nedenledir ki bu makalenin başlı̆̆ ilk bakışta çelişkili görünen iki ifadeyi bir araya getirmektedir: üretkenlik ve sanatsal üretim kaygısı. Oliphant, özyaşamöyküsünde, hem büyük bir aileyi geçindirmekle yükümlü tek kişi ve hem de bir kadın yazar olarak yaşadığı mutsuzluk, endişe ve zorlukları itiraf eder adeta. Dönemin önemli edebi kişiliklerinden biri olmasına rağmen hiçbir zaman gerçekten başarılı ve takdir edilen biri olarak görülmediğinden dem vurur. $\mathrm{Bu}$ bağlamda, bu makale Margaret Oliphant'ın Otobiyografi'sini son derece üretken bir yazarın yazarlık deneyimi süresince duyduyu endişe ve sıkıntıları göz önüne seren bir itiraf anlatısı olarak inceleyecektir.

Anahtar sözcükler: Margaret Oliphant, Otobiyografi, Üretkenlik, Sanatsal Üretim Kaygısı

\footnotetext{
* Res. Assist. Dr., Kocaeli University, Faculty of Sciences and Letters, Department of Western Languages and Literatures, Kocaeli. sedacosar@gmail.com This article is an extended and revised version of a paper presented at " $8^{\text {th }} I D E A$ Conference 'Studies in English"” that took place on 16-18 April 2014 at Muğla Sttk1 Koçman University, Muğla, Turkey. It has not been published elsewhere before.
} 
Although her name is mostly known to specialists in the field of Victorian literature and culture, Margaret Oliphant (1828-1897) was a very well known literary figure in her day. She was after all “Queen Victoria's favourite novelist" (Sutherland 1989, 477). As she writes in her Autobiography, she wrote her first novel at the age of sixteen to keep herself busy at a time of distressing conditions:

"In a time of my depression and sadness my mother had a bad illness, and I was her nurse, or at least attendant. I had to sit for hours by the bedside and keep quiet. I had no liking then for needlework... so I took to writing. There was no particular purpose in my beginning except this, to secure some amusement and occupation for myself while I sat by my mother's bedside" (1990, 24).

A few years later, in her early twenties, she began publishing novels as an enthusiastic young novelist. In time, writing became her only means of economic subsistence. When she died, she left behind over ninety novels in various literary genres, countless short stories, and a remarkable number of non-fictional works, including political essays, literary \& social criticism and many biographies of significant figures of the time. The total sum of her work can sound implausible at first glance, but her economic condition can explain why she had to produce so fast and so much. Even though she could not secure a canonical status later in the twentieth century, Oliphant was an active story-teller in a culture where story-telling was a social phenomenon as Victorians were rapid and ardent novel devourers.

As will be explained in detail in the next section, Margaret Oliphant was left a widow in her early thirties and writing was the most appropriate means for her to earn a living. She thus found herself as the one and only provider of a large, extended family. In situations such as this, balancing professional and personal lives becomes an ordeal for women as they have to put in a tremendous amount of effort to balance both, which is the concern of Oliphant's entire Autobiography. This phenomenon has created heated discussions in the field of women's studies. Especially in the second half of the twentieth century, different feminist standpoints problematized the issue of balancing working women's domestic and professional lives, putting the emphasis on the double burden put on working women's shoulders. This was even more difficult for women writers back in the nineteenth century because, as wives, mothers and daughters, they had to meet the expectations of the male-dominated Victorian patriarchy; yet, at the same time, they had to write for the Victorian publishing market to survive in a century that produced all-time bestseller authors. Margaret Oliphant's Autobiography encapsulates many instances revealing her pain, agony and internal guilt resulting from this double burden because she never felt in consequence of this double burden either competent as a writer or as a mother.

Autobiography in the Victorian period was very prevalent as a part of the story-telling culture. Both eminent and ordinary people were writing their life stories through diaries, memoirs, and autobiographies; yet, autobiography writing was especially popular in the Victorian society. In his article entitled "The Victorian Approach to Autobiography," Keith Rinehart (1954) writes that:

"The Victorian attitude toward autobiography may be divided into two aspects which have a rough correspondence to the traditional definition of the functions of literature-to instruct and to delight. The early Victorian emphasis was upon autobiography as a moral influence; the later, upon autobiography as art; but both united in their emphatic appreciation of autobiography" (178). 
Autobiography is also considered as confessional writing and Margaret Oliphant's Autobiography falls into this category in that it reveals an extremely productive woman writer's dilemma as an artist. As a matter of fact, this dilemma was common to most women writers of the period because many women wrote first and foremost to obtain money. Therefore, though novel writing was a process of artistic creation, which may require time and seclusion, many women writers were devoid of both. They had thus to meet the expectations of both their publishers and their readership, which is why they had to write most of the time under pressure. Throughout her writing career, Margaret Oliphant had to write under these conditions. Even though Oliphant was producing different types of both fictional and non-fictional works at an incredible speed, she was at the same time suffering from the anxiety of artistic creation, which can be defined as the artists' agony that troubles them before and during the creative process. Such an anxiety is a predicament faced by artists, which causes them to experience unease, fear and discontent with what s/he has created or is yet to create. In her Autobiography, Margaret Oliphant frequently expresses these and similar pessimistic feelings. The text is not a chronological narrative of day-by-day events. Rather, it is a gloomy account of her feelings and experiences as an overwhelmed mother, a middle-class widow, a provider for a huge family and a woman writer, who only barely felt self-fullfilled, accomplished, and appreciated in both her professional and personal lives. Margaret Oliphant's maternal sufferings, economic hardships and her affective experiences with the prominent women writers of the same period occupy a large place in her Autobiography, which may serve as a confession in many respects. This article aims to examine such entries concerning these matters in Oliphant's Autobiography as hints of an exceptionally prolific writer's later confessions about her emotional turbulence as a professional woman writer.

\section{Living through Pen and Paper as a Victorian Experience}

The Victorian era witnessed the rise of novel publishing. It would not be inappropriate to state that it was a period in which novel-reading was central to many facets of life. First, it served as a leisure activity for nearly everyone because Victorians were extremely fond of novels and they "did not have to possess literary taste or scholarly interest in order to read fiction. Simply there was no alternative" (Stevenson 1973, 394). In her Autobiography, Margaret Oliphant acknowledges the same phenomenon: "Our pleasures were books of all and every kind, newspapers and magazines, which formed the staple of our conversation, as well as all our amusement" (1990, 24). Secondly, novel writing was also influential in policy making. It is worthy of brief note here that even the then Prime Minister Benjamin Disraeli, (1804-1881) ventured into novel writing. He published three novels, Coningsby (1844), Sybil (1845), Tancred (1847), which are now grouped under the genre called 'The Condition of England Novel.' The novels clustered under this category aimed at drawing attention to economic, social and political problems of the time, perhaps to influence policy making processes, albeit indirectly of course. That means, the novel was thought of as a quick way to reach the public and influence their opinions because Victorians were avid novel readers. Regardless of class and gender, almost everyone literate was a novel consumer in the Victorian era:

"The ability to read, though not necessarily with ease and comprehension, was more widely shared than ever before, and the expanding middle class and to some degree the working class enjoyed an increased amount of disposable income they could spend for nonessential purposes such as books and periodicals" (Altick 2008, 290). 
Third, publishing novels was a decent way of earning a living for many people from various social and economic backgrounds. Artists, politicians, governesses, maids, wives, widows etc. were producing fiction to make their lives through pen and paper. In short, everyone was eligible as a novel writer for the following reasons:

"The profession was all the more alluring because it was open to all talents, the first respectable Victorian occupation to be an equal opportunity, affirmative action employer. It required no capital or equipment beyond one's active mind, an inkwell, pens, a quire of paper, and postage. Social rank was not a consideration, since manuscripts could be submitted by mail, with only a signature, or a pseudonym, to indicate the author. Nor was gender, as is attested by the number of women who entered the field" (Altick 2008, 298).

Apparently, writing served as a source of income for a large number of people from different social classes. This was particularly so for women, who did not have much agency, visibility, power and influence within Victorian patriarchy. Numerous women thus turned to writing to make money, which can be one way of explaining the blossoming of women novelists in the Victorian era. In her work entitled A Victorian Album: Some Lady Novelists of the Period, Lucy Poate Stebbins (1966) explains the extraordinary prominence of Victorian women in the publishing market by stating that women write fiction because they "must make money, must express [themselves], must redress a social wrong" (4). Even though the incentives that Stebbins notes can be true for writers from both sexes, many women in the Victorian period wrote primarily for economic reasons, due to lack of decent occupation opportunities for women in the public sphere. In A Literature of Their Own, Elaine Showalter directs attention to the extraordinary productivity of women novelists, noting that many women of the time took up writing as a profession because not many jobs were available to them (46-7). Margaret Oliphant was only one yet perhaps the best remembered of those women, who produced both fictional and non-fictional works primarily to make ends meet:

\begin{abstract}
"Many women wrote out of economic necessity. Margaret Oliphant nearly became destitute when her husband became ill, necessitating their relocation, and she then undertook supporting the children of her brother. Unfortunately, none of her children ever became financially independent, and Oliphant constantly felt compelled to write as many books as she could as quickly as possible" (Bloom 2000, 9).
\end{abstract}

Margaret Oliphant's arduous career as a writer turned more painful after her husband died leaving her "with two helpless children and one unborn, and very little money" (Oliphant 1990, 78). She further pictures the early days of her widowhood in the following way: "When I thus began the world anew I had . . about $£ 1000$ of debt, a small insurance of . . £200 on Frank's life, our furniture laid up in a warehouse, and my own faculties . . to make our living and pay off our burdens by" (Oliphant 1990, 78-79). As the sole income producer for her family, Oliphant did not even have time to mourn the loss of her husband:

"I fancy that I must have made a run up to London from Edinburgh in the summer of 1861, and stayed with Mrs Powell in Palace Gardens - a sister of Maurice, who had been very kind and friendly to me for a year or two before my husband's death. This must have been my first visit to her after, for I remember that she questioned me as to how I was left, 
and that I answered her cheerfully, with my head and hands to provide for my children, and was truly surprised by her strange look and dumb amazement at my cheerfulness" (Oliphant 1990, 96).

It would be unfair and unrealistic to expect literary perfection and consistency from a writer, who had to publish very frequently, without having the chance to polish her writing. Though many writers throughout history have faced similar or worse conditions, Oliphant's case is unique in that she published over ninety novels in addition to hundreds of shorter works (short stories, articles, reviews, commentaries etc.) and she was at times very anxious, unhappy, and discontented about her work as a novelist. Apparently, she was suffering from anxiety of artistic creation, a profound agony (The wording here may evoke psychoanalytic approaches to the artists' creation processes, but enriching the analysis in this line would exceed the scope of this article, whose deliberate choice is to focus only on Margaret Oliphant's personal lifelong struggle as a woman novelist in the Victorian era), which might have precluded her from releasing her true potential as a novelist. In this regard, her Autobiography serves as a sincere outpouring in the sense that Margaret Oliphant unburdens her heart, reveals the complexities of her personal life as a widow and a writer, who tried hard to survive in an era that produced verywell paid popular women writers such as Mary Elizabeth Braddon, Ellen Wood as well canonical authors such as The Brontë sisters, George Eliot, and Elizabeth Gaskell. Hence, Margaret Oliphant's Autobiography, as Timothy Peltason perfectly puts it, can be thought of as "a story of industry and self-sacrifice" (2008, 369). Inescapably, it is also a confessional lamentation of a professional woman.

\section{Margaret Oliphant's Autobiography as a Confession}

Margaret Oliphant's Autobiography is a confessional narrative in the way that it reveals a productive writer's inner life, her domestic burdens, economic hardships and her struggle to survive among the prominent women novelists of the time. That her endeavors to gain a seat among the canonical names of the Victorian epoch fell flat also makes her Autobiography a work of sentimental writing. Throughout her writing career, Margaret Oliphant's agony regarding her work stemmed from two different kinds of tough experiences: (1) her experience as a distraught mother and provider for a large family and (2) her experience as a professional woman writer, who had to cope with the rivalry amongst the promising writers of the period.

Margaret Oliphant continued writing throughout her life amidst the hustle and bustle of daily life and she "refused no work that was offered to" her, as she lucidly writes in her Autobiography $(1990,133)$. She had to produce as much and fast as humanly possible so that she could be paid only a modest amount of money:

"I never was very highly paid for my work, and perhaps this had its effect too on my carelessness in pecuniary matters. I made enough to carry me on easily, almost lavishly but not enough to save, never a large sum which could be partly put away at once and give one taste of the sweetness of possessing something" (Oliphant 1990, 117).

In addition, Margaret Oliphant was an ill-fated mother. She was not only left a widow at what can be considered a quite early age with two little children solely dependent on her for sustenance and one unborn baby, but she also had to bear witness to the untimely deaths of each of her children. No doubt this also contributed to her anxiety and unhappiness. It is hence understandable that Oliphant's Autobiography was written in a "grief-stricken light" (McLean 1996, 81). The text is not linear, neat and well-organized. Rather, it has been interrupted many 
times and her "writing . . c coincides with the death of [her] children" (McLean 1996, 81). Her grief each time she lost a child was so strong that this, too, aroused onerous anxiety. This can be felt from the bitter way Oliphant put her fears into words when writing about her eerie dialogue with Mary Howitt (1799-1888), a renowned poet of the Victorian period:

"It was at their house, I think, that we met the Howitts--Mary Howitt, a mild, kind delightful woman, who frightened me very much, I remember, by telling me of how many babies whom she had lost through some defective valve in the heart, which she said was somehow connected with too much mental work on the part of the mother,--a foolish thing, I should think, yet the same thing occured twice to myself. It alarmed and saddened me terribly" (1990, 40).

Apparently, Margaret Oliphant was suffering from a guilty conscience, perhaps because her mind was constantly preoccupied with what she was due to write. She felt herself as " $a$ sort of machine, so little out of order, able to endure all things, always fit for work whatever has happened" (Oliphant 1990, 56). It may be expected that at times she felt responsible for the death of her children. The gloomy atmosphere of the entries in Oliphant's Autobiography permeates the whole text, making it a sort of melancholic narrative disclosing her vain efforts to be a great writer in an age which created timeless novelists.

In addition to her maternal sufferings, Margaret Oliphant's Autobiography also casts a light upon her striving to survive amongst the extremely talented and promising women novelists of the period. She knew that the material conditions of her life were compelling when compared to the canonical names of the same period such as George Eliot, Elizabeth Gaskell and the legendary Brontës. She could not help comparing her writing experience with the rewarded careers of such favorable figures in the Victorian publishing market:

"In this my resolution which I did make, I was after all, only following my instincts, it being in reality easier to me to keep on with a flowing sail, to keep my household and make a number of people comfortable at the cost of incessant work, and an occasional great crisis of anxiety, than to live the self-restrained life which the greater artist imposes upon himself' (Oliphant 1990, 16).

Although she was very well known in the Victorian period and some of her works at times became bestsellers, Margaret Oliphant herself felt that her name would be forgotten in time. Her Autobiography reveals that her aspiration to write like George Eliot and Charlotte Brontë was so high that she underestimated the value of her own works. She could not escape comparing herself with the literary stars of the Victorian age. This for instance is her comment on Charlotte Brontë:

"I was reading of Charlotte Brontë the other day, and could not help comparing myself with the Picture more or less as I read. I don't suppose my powers are equal to hers-my work to myself looks perfectly pale and colorless beside hers-but yet I have had far more experience and, I think, a fuller conception of life" $(1990,10)$.

George Eliot occupies a significant place in Oliphant's Autobiography. "No one even will mention me in the same breath with George Eliot," she writes $(1990,17)$ and, at some point, she openly faces her feelings by asking herself whether she is " $a$ little envious of her" $(1990,14)$. 
However, Margaret Oliphant was aware of the sharp contrast between George Eliot's lofty life style and the tough conditions of her own life: "How I have been handicapped in life! Should I have done better if I had been kept, like her, in a mental greenhouse and taken care of? This is one of the things it is perfectly impossible to tell" $(1990,15)$. "Mental greenhouse" is an interesting expression to define George Eliot's reclusive life as an artist and the highbrow circle she was enjoying as an intellectual. Here, Oliphant might have implied that as a childless woman, George Eliot did not have any domestic obligations. Also, the intellectual and romantic relationship she enjoyed, living with George Henry Lewes encouraged and fostered her as a novelist. Hence, "mental greenhouse" is an apt analogy to describe the secure life of George Eliot, who could direct all her artistic energy, time and attention exclusively to her work.

Conversely, Oliphant's writing career was not as elegant as George Eliot's. Both during the early and late phases of her writing career, Oliphant could not find refuge in a secluded place as an artist:

"[T]he writing ran through everything. But then it was also subordinate to everything, to be pushed aside for any little necessity. I had no table even to myself, much less a room to work in, but sat at the corner of the family table with my writing-book, with everything going on as if I had been making a shirt instead of writing a book. Our rooms in those days were sadly wanting in artistic arrangement. The table was in the middle of the room, the centre around which everybody sat with the candles or lamp upon it. My mother sat always at needle-work of some kind, and talked to whoever might be present, and I took my share in the conversation, going on all the same with my story" (Oliphant 1990, 30).

This tumultuous scene neither changes in her brief marriage life, nor later in her widowhood as she additionally writes: "I don't think I have ever had two hours undisturbed (except at night, when everybody is in bed) during my whole literary life" (1990, 30). Such comparisons sound like an outbreak when Oliphant woefully states: "George Eliot and George Sand make me half inclined to cry over my poor little unappreciated self" $(1990,17)$. Whenever Margaret Oliphant talks about herself as a writer in her Autobiography, she cannot help comparing her writing with the works of the highly accomplished women writers of the same period. Yet, such an attitude was not peculiar only to Oliphant, there was an inclination to treat "George Eliot as a touchstone against which other women writers would be compared" (Thompson 1999, 8). Apparently, such comparisons generated feelings of self-hatred in Margaret Oliphant towards her own work. She eventually turned out to be the harshest critic of her own writing. Margaret Oliphant wrote her first professional novel, Passages in the Life of Mrs. Margaret Maitland, in 1849, when she was twenty-two years old. Later, in her Autobiography, she avowed that she did not consider it a good novel: "When I read it over some years after, I felt nothing but shame at its foolish little polemics and opinions" $(1990,29)$. Still, some of her works competed with the canonical and sold very well in the same period. Even during those times, Oliphant tended to underestimate the quality of her writing, which might be an inkling that she never gained selfconfidence as a writer due to the intolerable angst she was suffering from.

Margaret Oliphant gained a great success with Chronicles of Carlingford, a series of church novels, which were published anonymously. The series included her best remembered works today; Salem Chapel (1863), The Rector and the Doctor's Family (1863), The Perpetual Curate (1864), Miss Marjoribanks (1866), and Phoebe Junior (1876). Contemporary critics agree that Chronicles of Carlingford "represent the peak of her achievement" (Terry 1983, 74). In her 
biography of Margaret Oliphant, Merryn Williams (1986) states that "Margaret Oliphant is still best remembered as the author of the Chronicles of Carlingford, which, as she said, 'made a considerable stir at the time and almost made [her] one of the popularities of literature" (91). Chronicles of Carlingford was so appreciated that the authorship was "attributed to George Eliot who ... was then at the zenith of her fame" (Melville 1906, 261). The confusion about the writer of the novel forced George Eliot to announce publicly that she was not the writer (Shattock 1980, 231). Oliphant, too, felt that she had to defend herself against this confusion of authorship. This is what she wrote to her publisher John Blackwood:

"A high compliment to me, no doubt; but women, you know, according to the best authorities, never admire each other. . the faintest idea of imitating or attempting to rival the author of 'Adam Bede' never entered my mind" (qtd. in Williams 1986, 43).

No one will deny that George Eliot's writing was the highest standard that could be used to evaluate one's success as a writer in the Victorian era. Apparently, Margaret Oliphant takes it as an honour; yet, on the other hand she never considers this an opportunity to raise her standards and enter into different intellectual classes. Rather, she prefers to resign herself to her own small circle, and denies rivalling one of the biggest names of the period. This may either show her humbleness or her lack of confidence.

Margaret Oliphant could not find a place in the literary canon of the Victorian period. Many contemporary critics who work on Oliphant cannot escape discussing the reasons for her exclusion from the Victorian canon. Critics agree on the idea that it is her extreme productivity which overshadowed her reputation. In "The Paradoxes of Oliphant's Reputation” John Stock Clarke (1995) writes that "she crippled her talent by overproduction" (33). George Saintsbury's (1976) comment on the same issue is also noteworthy:

“In Mrs. Oliphant's case we ask, how could any human being, on such a system of production, be expected to produce masterpieces? Scott, I think, once wrote four or nearly four novels in a year: and the process helped to kill him. Mrs. Oliphant did it over and over again, besides alternating the annual dose still more frequently with twos and threes. In her case the process only killed her novels" (286).

One should consider, however, that she was the breadwinner of a large family and a domestic worker at home, which explains why, her Autobiography "enacts the struggle to find voice while emerging as an apologie for not having written a masterpiece” (McLean 1996, 82). Seemingly, Oliphant never believed that she could create a masterpiece that would have carried her name to future generations. She did not feel happy and self-confident about her writing, which she reflected in her Autobiography, particularly in the times of angst and fury. This can most remarkably be felt in the extreme, when she writes: "I feel myself like the sufferers in Dante ... who are bent under the weight of stones" $(1990,99)$. Apparently, she felt overpowered by the burdens of life and "the weight of stones" resulted from the two roles that she found so difficult to balance: her role as the provider and homemaker of an extended family and her role as a woman artist, who needed more time, energy, endorsement, and seclusion to create an abiding work of art. She had none, because of which she suffered from anxiety of artistic creation. This does not mean that she was concerned about her creativity as an artist. On the contrary, in Margaret Oliphant's case, she was productive perhaps more than anyone else. However, in time, her productivity gave way to a sort of exhausting agony, because her work did not have the 
potential to compete with what the masters of the age were producing. As she confesses in many places in her Autobiography, Margaret Oliphant was grievously aware of the fact that her mothering experience and her authorship were both doomed to make her feel anxious and disillusioned.

\section{Conclusion}

In the final pages of her Autobiography, Margaret Oliphant relates the death of her last child alive, Cecco: "And now here I am all alone. I cannot write any more" $(1990,154)$. It is worthy of note that she abandoned writing at a time when she had no one left to take care of. However, there is no doubt that her mind was still suffering from the loss of her children. This might be indicative of the fact that writing could not function as an artistic activity for Oliphant, which resulted in on and off anxiety moments that she candidly reflected in her Autobiography. Rather, writing had down-to-earth functions for her. She endeavoured to gain enough money to make ends meet through her pen; and, it is highly likely that she found refuge in writing: "I have always been most grateful to God that it was work I liked and that interested me in the doing of it, and it has often carried me away from myself and quenched, or at least calmed, the troubles of life" (Oliphant 1990, 117-118). This may signal the therapeutic influence of writing in that Oliphant tried to forget her daily struggles and psychological traumas by devoting herself to writing. Paradoxically, however, too much writing also worried her because it affected the quality of her work, making her feel herself inferior when compared to the outstanding literary figures of the Victorian epoch.

As the writer of both fictional and non-fictional works of various kinds, Margaret Oliphant had both economic and artistic concerns. However, she had to supress her concerns as an artist because of economic priorities for she always had to produce in short periods of time. When seen from this perspective, Margaret Oliphant's Autobiography holds a special importance among her complete works because it presents a record of her ordeal as a middle-class widow, who had to cope alone with the exhausting burden of a large family. This makes the text a kind of confession in that Oliphant most of the time discharges her overwhelmed mind, which might have created a remedial influence. As this article aimed to highlight, Margaret Oliphant's Autobiography is a proper source to show the ups and downs of a woman's writing career in the Victorian publishing market, her turbulent struggle to thrive as a notable novelist in the golden age of the novel, and her depression and angst as an artist, who managed to astonish almost everyone with her prolificacy. 


\section{REFERENCES}

Altick R. D. (2008). Publishing. Ed. H. F. Tucker, A Companion to Victorian Literature \& Culture, 289304. Malden, U.S. 2008.

Bloom, A. B. (2000). Introduction. Ed. A. B. Bloom, Nineteenth-Century British Women Writers A BioBibliographical Critical Sourcebook, 1-10. Westport U.S. 2000.

Clarke, J. S. (1995). The Paradoxes of Oliphant's Reputation. Ed. D. J. Trela, Margaret Oliphant: Critical Essays on a Gentle Subversive, 33-49. London, U.K. 1995.

McLean, J. A. K. (1996). Writing Women's Lives: A Study of Victorian Women's Autobiography. (Unpublished PhD. Dissertation). New York University. New York, U.S. 1996.

Melville, L. (1906). Victorian Novelists. London, U.K.1906.

Oliphant, M. (1990). Ed. E. Jay, The Autobiography of Margaret Oliphant. Oxford, U.K. 1990.

Peltason T. (2008). Life Writing. Ed. H. F. Tucker, A Companion to Victorian Literature \& Culture, 356372. Malden, U.S. 2008.

Rinehart K. (1954). The Victorian Approach to Autobiography. Modern Philology, 51/3, 177-186 1954.

Saintsbury, G. (1913-1976). The English Novel. New York, U.S. 1913-1976.

Shattock, J. (1980). Oliphant, Margaret (Oliphant, née Wilson). Ed. J. Vinson, The Novel to 1900, 227231. London, U.K. 1980.

Showalter, E. (1977-1988). A Literature of Their Own: British Women Novelists from Bronte to Lessing. London 1988.

Stebbins, L. P. (1946-1966). A Victorian Album: Some Lady Novelists of the Period. New York U.S. 1946-1966.

Stevenson, L. (1973). The Rationale of Victorian Fiction. Nineteenth-Century Fiction, 27/4, 391-404 (1973). Doi: 10.2307/2933516.

Sutherland, J. (1989).The Stanford Companion to Victorian Fiction. Stanford, U.S. 1983.

Terry, R. C. (1983). Victorian Popular Fiction, 1860-80. Hong Kong 1983.

Thompson, N. D. (1999). Responding to the Woman Questions: Reading Noncanonical Victorian Women Novelists. Ed. N. D. Thompson, Victorian Women Writers and the Woman Question, 1-24. Cambridge, U.K. 1999.

Williams, M. (1986). Margaret Oliphant: A Critical Biography. New York, U.S. 1986. 